\title{
Lisa Drakeman
}

Seizing upon a favorable business climate in Europe, US businesswoman Lisa Drakeman has blended goal-oriented American culture with a European focus on team effort to move her firm's antibodies closer to the market.

A husband and wife running separate antibody companies located on two continents? Sounds like a recipe for marital strife. But for Lisa Drakeman, CEO of Copenhagen's GenMab and Don Drakeman, of Princeton, New Jersey-based Medarex, it's working. After only 6 years in business, Lisa has taken her company public, ushered five products into the clinic, made more partnerships than she can name and raised half a billion dollars for the company's coffers. As she emerges from the shadow of her better known husband, Drakeman is establishing herself as a business person in her own right, and antibodies as therapeutics, making believers out of once skeptical pharma companies.

Much of the success of Medarex and GenMab can be traced to the former's HuMab technology, which produces fully human monoclonal antibodies (mAbs) in transgenic mice. But GenMab offers more than a platform, according to Scott Foraker, vice president of licensing at Amgen of Thousand Oaks, California, which inherited a mAb deal with GenMab when it acquired Immunex in 2001. Drakeman also assembled a credible team for pushing drug candidates through early-stage clinical trials, according to Foraker. In fact, Amgen was so impressed with the results of their joint venture to commercialize AMG714-a human mAb against interleukin-15 currently in phase 2 clinical trials for rheumatoid arthritis-they renegotiated the deal to get earlier access to it. "We were sufficiently intrigued that we ended up cutting a new deal that enabled us to engage earlier in the development process and do the heavy lifting by maximizing our clinical and commercial manufacturing resources," he says.

With a job teaching in the history department at Princeton, Drakeman had no thoughts of a career in biotech until she was enlisted in 1989 to volunteer at her husband's company when they couldn't afford to hire anyone. But after a few years heading up business development at Medarex, she was wooed away by a group of Danish venture capitalists to run their startup, a company she helped to conceive with the idea that having a partner in Europe would allow Medarex to extend use of their technology beyond the US and would provide a place to fund and control development of some of its products. Drakeman says that running a company in Europe seemed far-fetched because she had a growing family in the US at the time, but she agreed to do it, fully expecting that the company would find someone in Europe to take over. Six years and countless intercontinental trips later, she's rather hoping to keep her job, as she likes the industry, the pace and the opportunity to improve medical care.

Although licensing deals formed the basis of Medarex's business strategy at that time, Drakeman brought a different vision to GenMab. She sees value in low-risk, low-reward deals, but knows that they are not enough to sustain a business or keep employees satisfied. "Typically biotech products ramp up sales pretty quickly. We hope that we can balance the low revenue stream [from royalties and milestones] with some pretty significant revenues on the high end," she says.

Choosing to build the company in Denmark has had ramifications not only for the company but personally for Drakeman. Denmark offered easy access to capital, the biopharmaceutical infrastructure needed for conducting clinical trials and unexploited scientific and commercial potential, according to Drakeman. And being one of the few biotech companies there brings the small firm visibility it would not get in the US.

Drakeman finds the European style of business different from that of the US. Europeans, and Danes in particular, bring their own sensibility to the table, fostering a social contract unlike the one she was used to. "In Denmark, people continue to live in the same place for generations, so you expect to see people again. It leads to a high standard of personal integrity. You have an obligation to a community, whether it's a business community, family or town," she says. Spending time in Denmark has changed her perspective on life in the US. Europeans have a more gracious lifestyle, Drakeman believes, one that she is learning to emulate.

Being situated in Europe has brought other, more tangible benefits-resources in the form of technologies and expertise that were not being fully exploited commercially. Drakeman has been trolling the continent for good targets. "Getting access to a technology that makes good antibody is one thing, but you have to have a good disease target that you think an antibody will be effective against," she says.

We make a nice
combination of
American goal-oriented
way of doing things with
a European approach,
which is more focused
on thinking about what
we can do as a team.

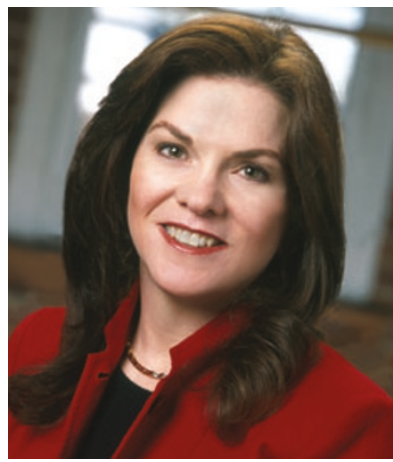

And she has gained access to some through partnerships and insolvencies-she scooped up 16 targets from the failing German company Europroteome, one of which is already being used in development.

Sally Bennett, director of biotech research at ING Wholesale Banking in London says GenMab stands out among European antibody companies in having multiple business strategies as well as multiple products in clinical development. However, even with half a billion dollars to work with, GenMab will be dependent on partners for some time yet, she says. Taking products through multiple pivotal clinical trials - which Bennett believes some of GenMab's candidate drugs will require-is just too expensive for a small biotech.

But GenMab is not going to have trouble finding that kind of help as demonstrated by the deal with Serono announced just last month-Serono is taking on development and commercialization of a Mab against CD-4 antigen for treating T-cell lymphomas currently in pivotal trials, a deal which could bring in as much as $\$ 200$ million all told. Drakeman herself has noticed a change in attitude at pharma companies. She recalls being told 10 years ago that antibodies will never work. As much an optimist as pragmatist, her response then-and now: "'Well, we'll just have to wait and see."”

Laura DeFrancesco, Pasadena 